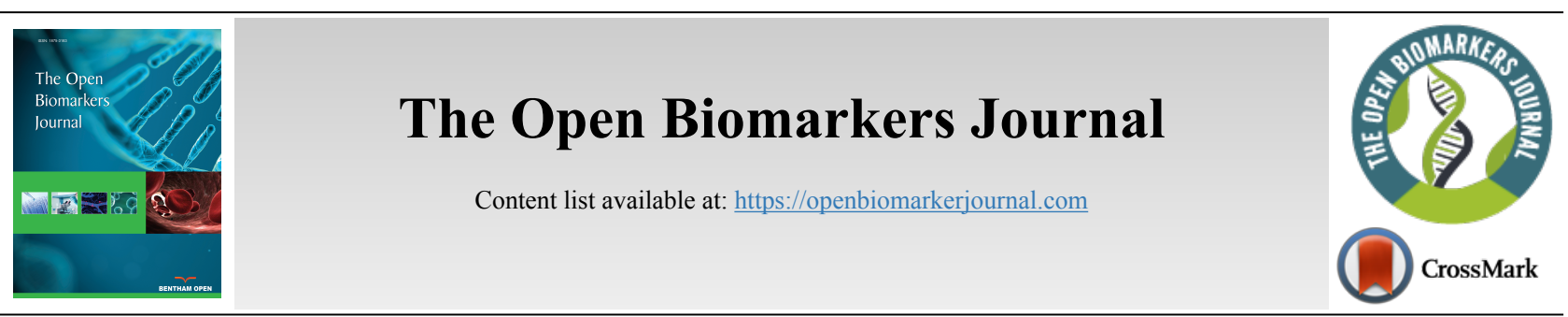

EDITORIAL

\title{
Biomarkers are the Need of the Present Era
}

\author{
Chandra K. Sharma ${ }^{1, *}$ and Monika Sharma ${ }^{2}$

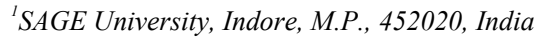 \\ ${ }^{2}$ Banasthali Vidyapith, Rajasthan, 304022, India
}

The advancements in medicine and public health measures have made possible, the worldwide decline in the incidence and prevalence of infectious liver diseases (i.e., viral, bacterial, fungal, parasitic etc.) However, with the changing pattern of lifestyle, most of the diseases are now associated with the lifestyle and the chemical-induced diseases are increasing paradoxically in recent years to become a major health problem in the near future. So this thematic issue was conceptualized in view to give comprehensive latest information related to the biomarkers used in the medical sciences.

The toxicologically important xenobiotics may get access into the body as environmental contaminants (food, water, and air) or are administered inadvertently with therapeutic and suicidal intentions. As the most important organ in the body, primarily, the liver is involved in the biotransformation of drugs, food, exogenous and endogenous substances. The term biomarker was introduced first in 1980. A biomarker is an attribute which is logically considered as an indication of usual biological machinery, the process of pathogenesis or responses related to the pharmacological level to a therapeutic association $[1,2]$. According to WHO, the united nations and the international labor organization coordinate the international program for the chemical safety, which was organized by WHO giving another definition of the biomarker, "a measurable biochemical, physiological, behavioural or other alteration within an organism that, depending upon the magnitude, can be recognized as associated with an established or possible health impairment or disease" [3]. At the present time, biomarkers are highly important for unifying discovery of the drug and day by day improvements. They are expected to be extensively used in the examination of a disease in medical research. Classes of biomarkers may be prognostic biomarkers, pharmacodynamic biomarkers, surrogate endpoints and predictive biomarkers [4 - 6].

In the current scenario, biomarkers have a crucial role in the detection of a drug; biomarkers can be used to understand

\footnotetext{
* Address correspondence to this author at SAGE University, Indore, M.P., 452020, India; E-mail: ck21sharma@rediffmail.com
}

the mechanism of action of a drug, efficacy and probability of toxicity at the primary stage of development of pharmaceuticals and in the diagnosis of patients likely to respond towards medication. Consequently, biomarkers have been used in the assessment of the safety of drugs in clinical practice in addition to personalization of medicines. However, some reliable biomarkers at present may predict that who will be the positively responsive group of patients, group of nonresponsive patients and who may show negative reactions to the dose and interventions. Nowadays, the risk of increasing hepatotoxicity is due to a complex reciprocal relationship among the chemical properties of the drug, sex, age, diseases as well as genetic factors $[7,8]$. About 14 to 19 per 100,000 individuals of general populations are rated for drug-induced liver toxicity $[9,10]$. While in an active and responsible group, the frequency estimated is about thirty to thirty-three per ten thousand individuals [11]. Hence, there are a huge number of studies and research being conducted on biomarkers. In this special issue, some very good papers are included for the benefit of the scientific community. The first paper deals with acute toxicity and efficacy of nanomaterial based decontamination formulations developed for personal decontamination against chemical warfare agents. In this paper, the study addresses the efficacy of nanomaterials based formulations used in Personal Decontamination Kit (PDK). In this paper, emphasis has been given to biomarkers, which perform a significant function in the process of drug development. Biomarkers have been utilized in the safety assessment of drugs in clinical practice and also for personalization of medicines. The use of biomarkers in clinical as well as basic research has been promoted rapidly by the different drug regulation authorities for better outcomes in the future. Another paper deals with protective efficacy of vitamin $F$ against acrylamide induced toxicity and studies on oxidative stress biomarkers. In this paper, the significance of vitamin $\mathrm{F}$ has been discussed. Vitamin F, is also known as Linoleic Acid (LA), is an Essential Fatty Acid (EFA) which is not produced in humans. It can be modified to form essential precursors such as arachidonic acid which is used to make prostaglandins, 
thromboxanes, and leukotrienes. We thank all the researchers who have contributed to this special issue, we are also thankful to the Bentham Open for publishing this special issue.

\section{REFERENCES}

[1] Strimbu K, Tavel JA. What are biomarkers? Curr Opin HIV AIDS 2010; 5(6): 463-6.

[http://dx.doi.org/10.1097/COH.0b013e32833ed177] [PMID: 209783 $88]$

[2] Gosho M, Nagashima K, Sato Y. Study designs and statistical analyses for biomarker research. Sensors (Basel) 2012; 12(7): 8966-86. [http://dx.doi.org/10.3390/s120708966] [PMID: 23012528]

[3] 1993.http//www.inchem.org/documents/ehc/ehc/ehc155.htm

[4] Jenkins M, Flynn A, Smart T, et al. A statistician's perspective on biomarkers in drug development. Pharm Stat 2011; 10(6): 494-507. [http://dx.doi.org/10.1002/pst.532] [PMID: 22162336]

[5] Ludwig JA, Weinstein JN. Biomarkers in cancer staging, prognosis and treatment selection. Nat Rev Cancer 2005; 5(11): 845-56. [http://dx.doi.org/10.1038/nrc1739] [PMID: 16239904]

[6] Buyse M, Michiels S, Sargent DJ, Grothey A, Matheson A, de
Gramont A. Integrating biomarkers in clinical trials. Expert Rev Mol Diagn 2011; 11(2): 171-82.

[http://dx.doi.org/10.1586/erm.10.120] [PMID: 21405968]

[7] Deleve L, Kaplowitz N, Wolfe M. Prevention and therapy of drug induced hepatic injury. In: therapy of digestive disorders 2000. Brace: Philadelphia WB Saunders: Harcourt 2000; pp. 334-48.

[8] Zimmerman H, Schiff E, Sorell M, Madding W. Drug-induced liver disease, Schiff's diseases of the liver. $8^{\text {th }}$ ed. Philadelphia Lippencourt Raven 1999.

[9] Sgro C, Clinard F, Ouazir K, et al. Incidence of drug-induced hepatic injuries: a French population-based study. Hepatology 2002; 36(2): 451-5.

[http://dx.doi.org/10.1053/jhep.2002.34857] [PMID: 12143055]

[10] Björnsson ES, Bergmann OM, Björnsson HK, Kvaran RB, Olafsson S. Incidence, presentation, and outcomes in patients with drug-induced liver injury in the general population of Iceland. Gastroenterology 2013; 144(7): 1419-25.

[http://dx.doi.org/10.1053/j.gastro.2013.02.006] [PMID: 23419359]

[11] Shin J, Hunt CM, Suzuki A, Papay JI, Beach KJ, Cheetham TC. Characterizing phenotypes and outcomes of drug-associated liver injury using electronic medical record data. Pharmacoepidemiol Drug Saf 2013; 22(2): 190-8.

[http://dx.doi.org/10.1002/pds.3388] [PMID: 23258383]

\section{C) 2019 Sharma and Sharma.}

This is an open access article distributed under the terms of the Creative Commons Attribution 4.0 International Public License (CC-BY 4.0), a copy of which is available at: (https://creativecommons.org/licenses/by/4.0/legalcode). This license permits unrestricted use, distribution, and reproduction in any medium, provided the original author and source are credited. 